\title{
INNOVATION OF BUILDING DESIGN BASED ON PREDICTED MEAN VOTE (PMV) INDEX FOR INCREASING HUMAN COMFORT
}

\author{
Sugiono \\ Industrial Engineering Department, Engineering Faculty of Brawijaya University \\ Jl. MT. Haryono No. 167, Malang 65145 - INDONESIA \\ Email: sugiono_ub@ub.ac.id
}

\begin{abstract}
Concerning towards the quality of air comfort and safety to pedestrians in the University area should be increased as Indonesia economics booming. The objective of this study is to investigate and then to evaluate the distribution of thermal comfort at the University of Brawijaya, Malang. The research is started with study literature and early survey to collect all information of building layout and building shape at the University of Brawijaya. The information is used to create a 3D model in CAD software. The model is simulated to measure the PMV factors of air temperature, relative humidity and air speed in some locations. The two scenarios of maintaining the predicted mean vote (PMV) is presented by designing the new building based on air foil shape dimension to keep the wind speed in higher value for pedestrian and by putting the water pool in front of the building to increase the air temperature. As a result, the air foil based design is capable to reduce PMV index in average 0.4 scale and pool design is only reducing PMV index level in 0.001 scale.
\end{abstract}

Keywords: Thermal comfort; PMV index; CFD; building design; CAD.

\section{INTRODUCTION}

Outdoor human comfort in the University climate may be affected by a wide range of factors that have been investigated in long period. Comfortable situation for pedestrians around the University are very important for occupants to support their activeties. Frequently, the management ignores the factors of thermal comfort in building of the University's facility. Extremely, there are some complaints from the occupants as heat stress condition including too hot, sweating, dizzy, etc. For comfort and efficiency works, the human body needs a fairly narrow range of environmental conditions compared with the full scope of those found in nature. The environment factors that affect humans pleasantly or adversely include (Bridger, 2003):

- Temperature of the surrounding air

- Radiant temperatures

- Humidity of the air

- Air motion

- Odors

- Dust

- Aesthetics

- Lighting

Microclimatic parameters around the University area depend on air/wind condition through the building, the University layout, building shape and building dimension. Wind speed through building may be deflected down to ground level by tall building causing uncomfortable and even dangerous for people
(Khalid et al., 2013). Fortunately, advance modeling technique like Computational Fluid Dynamic (CFD) can be used to simulate air/wind configuration which is very important to investigate the human thermal comfort. The CFD is a branch of fluid mechanics that uses numerical methods and algorithms know how fluid flows, and predict what will happens to the objects that are in contact with the fluid flow. The CFD also can provide significant cost benefits for studying, evaluating and optimizing the building design related to environment concern (Tsuyoshi, 2009).

Thermal comfort is defined in British Standard BS EN ISO 7730 as the condition and situation of human thinking which expresses satisfaction with the thermal environment level. Thermal comfort is described by psychological condition which is indicated by feeling to hot or too cold. In reality, thermal comfort is difficult to define as differentiate among people when deciding what will make them feel 'comfortable'. The Health \& Safety Executive (HSE) noted that the best measure of thermal comfort is indicated by how many people in the workplace feels satisfied with the level of temperature. Moreover, they consider $80 \%$ of occupants as a reasonable limit for the minimum number of people who should be thermally comfortable in an environment.

Geographically, Indonesia location is in tropical climate with temperature average $35^{\circ} \mathrm{C}$ and high relative humidity ( $>85 \%)$. The situation is also depending on the Indonesian position between two oceans and two continents. According to previous research, com- 
fort thermal for Indonesian is around temperature $22.8^{\circ} \mathrm{C}$ to $25.8^{\circ} \mathrm{C}$ with relative humidity $70 \%$ (Yayi, 2012). Generally, people will be sweating at temperature $26^{\circ} \mathrm{C}$. Human endurance and human productivity starts decline for temperature $26^{\circ} \mathrm{C}-30^{\circ} \mathrm{C}$. Really hard situation will happen for people in temperature between $33.5^{\circ} \mathrm{C}-35.5^{\circ} \mathrm{C}$. Environment temperature more than $36^{\circ} \mathrm{C}$ is not acceptable for people's productivity.

One of the technical parameters for measuring human comfort is predicted mean vote (PMV) index. The high PMV index value will disturb human performance and human health. The disorder can include fatigue, cramps, loss of concentration and heat stroke (Greenslade et al., 1997). To solve the problem, workplace air regulation becomes the main thing to produce optimum work performance. The research is focused on determining the human comfort for pedestrians who is walking or sitting at the Brawijaya University area. Computational Fluid Dynamics (CFD) software of Solid works is employed to define the predicted mean vote (PMV) index. The simulation results and the PMV values are used to declare some recommendations of increasing human comfort in Brawijaya University area.

\section{RESEARCH THEORY PREDICTED MEAN VOTE (PMV) INDEX}

Heat is a form of energy that flows through in medium (solid, gas, fluid) from a point at one temperature to another point at a lower temperature. There are two forms of heat of concern in processing for comfort: (1) sensible heat and (2) latent heat (Koch-Neilsen \& Holger, 2002). Sensible heat is the energy needed to increase a substance temperature with no change in phase. On the other hand, latent heat is the amount of energy needed to change a substance phase, as example from fluid to be steam.

Heat (temperature) and energy are to be the main factor in the performance of human activities. Human beings need a constant - temperature with the best internal body temperature around $98.6^{\circ} \mathrm{F}\left(37^{\circ} \mathrm{C}\right)$ (Bridger, 2003). Human body produces heat as metabolic activity and controls it by keeping the balance of metabolism. Given a set metabolic rate, however, the body must reject heat at the appropriate rate in order to maintain thermal equilibrium. If the internal temperature rises or falls beyond its normal range, mental and physical operation is curtailed, and if the difference of temperature is extreme, serious physiological disorders or annoyance of human healthy can be affected. Human bodies or animals occasionally rise their body temperature to keep immunological system working well to kill batteries and viruses.
To reach the outdoor thermal comfort, it is crucial to understand the concept of thermal comfort for the outdoor design, environmental parameters, social behavior and human physiological. To control the microclimatic, there are six key factors should be identified for environmental factors (air temperature, relative humidity, air speed and mean radiant temperature) and for personal factors (clothing insulation ratio and activity or metabolic heat rate) as described in Figure 1.

The key six factors are combined together on the thermal sensation scale which called a predicted mean vote (PMV) index. The PMV is derived from the physics of heat transfer combined with an empirical fit to human sensation. PMV establishes a thermal strain based on steady-state heat transfer between the body and the environment and assigns a comfort vote to that amount of heat stress. Table 1 shows 9 scales of PMV correlated to thermal perception and grade of physiological stress. PMV under -3.5 is categorized very cold in thermal perception with impact of extreme cold stress, PMV between -0.5 to 0.5 is categorized comfortable perception with no thermal stress and PMV above 3.5 is categorized very hot in thermal perception with the impact of extreme heat stress.

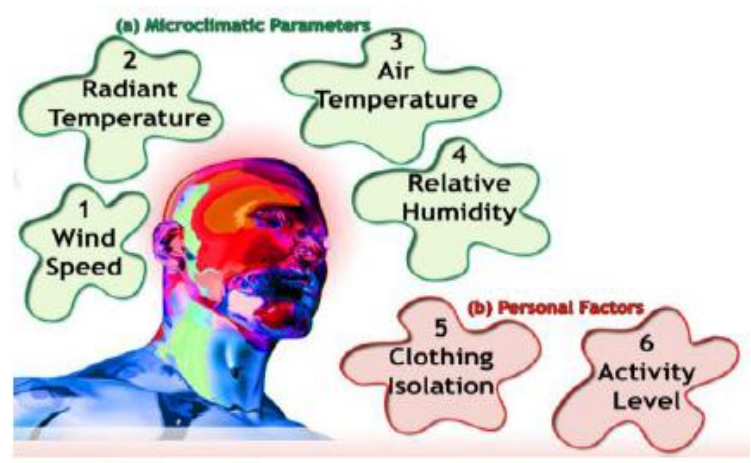

(Source: Khalid et al., 2013).

Figure 1. Thermal comfort interaction factors

Table 1. PMV Scales with Thermal Perception \& Grade of Physical Stress

\begin{tabular}{|c|c|c|c|}
\hline PMV & $\begin{array}{l}\text { PET } \\
\left({ }^{\circ} \mathrm{C}\right)\end{array}$ & $\begin{array}{l}\text { Thermal } \\
\text { Perception }\end{array}$ & Grade of Physiological Stress \\
\hline$>3.5$ & $>4$ & Very Cold & Extreme cold stress \\
\hline-3.5 & 4 & Cold & Strong cold stress \\
\hline-2.5 & 8 & Cool & Moderate cold stress \\
\hline-1.5 & 13 & Slightly cool & Slight cold stress \\
\hline-0.5 & 18 & Comfortable & No thermal stress \\
\hline 0.5 & 23 & Slightly & \\
\hline 1.5 & 29 & warm & Slight heat \\
\hline 2.5 & 35 & Warm & Moderate heat stress \\
\hline 3.5 & 41 & Hot & Strong heat stress \\
\hline$>3.5$ & $>41$ & Very hot & Extreme heat stress \\
\hline
\end{tabular}

(Source: Stanton et al., 2005) 
ISO 7726 - 1998 and ASHRAE 55-1992R described how to measure the PMV index according to key six factors. PMV for personal parameters of metabolic rate, clothing insulation and thermal environment can be formulated by the equation 1 (Stanton et al., 2005):

$$
\begin{aligned}
\text { PMV }= & \left(0.303 . \mathrm{e}^{-0.036 . \mathrm{M}} 0.028\right)\left\{(\mathrm{M}-\mathrm{W})-3.05 .10^{-3} .\right. \\
& {[5733-6.99(\mathrm{M}-\mathrm{W})-\mathrm{Pa}]-0.42 .[(\mathrm{M}-\mathrm{W})-} \\
& 58.15]-1.7 .10^{-5 \mathrm{M}}(5867-\mathrm{Pa})-0.0014 . \mathrm{M} \\
& (34-\mathrm{ta})-3.96 .10^{-8} . \mathrm{fd} .\left[(\mathrm{td}+273)^{4}-(\mathrm{t}+\right. \\
& \left.\left.273)^{4}\right]-\mathrm{fd} . \mathrm{hc}(\mathrm{td}-\mathrm{ta})\right\} \ldots \ldots \ldots \ldots
\end{aligned}
$$

and;

$t_{d}=35.7-0.028(\mathrm{M}-\mathrm{W})-I_{d}\left[3.96 .10^{-8} f_{d}\left[t_{d}+\right.\right.$ $\left.273]^{4}-\left[t_{e}+273\right]^{4}\right]+f_{d} h_{c}\left(t_{d}-t_{a}\right)$

$\mathrm{H}_{\mathrm{c}}=2.38\left(\mathrm{t}_{\mathrm{d}}-\mathrm{t}_{\mathrm{a}}\right)^{0.25}$ for 2.38. $\left(\mathrm{t}_{\mathrm{d}}-\mathrm{t}_{\mathrm{a}}\right)^{0.25}$

Where:

$\mathrm{PMV}=$ the predicted mean vote

$\mathrm{M}=$ metabolic rate $\mathrm{W} / \mathrm{m}^{2}$

$\mathrm{I}_{\mathrm{cl}}=$ Thermal resistence of the clothing, $\left(\mathrm{m}^{2}{ }^{\circ} \mathrm{C}\right) /$ W

$\mathrm{F}_{\mathrm{cl}}=$ ratio of the clothed surface area to the nude surface area

$\mathrm{t}_{\mathrm{a}}=$ the air temperature, ${ }^{\circ} \mathrm{C}$

$\mathrm{PMV}=$ predicted mean vote

$\mathrm{t}_{\mathrm{r}} \quad=$ mean radiant temperature, ${ }^{\circ} \mathrm{C}$

$\mathrm{v}_{\mathrm{ar}}=$ air velocity relative to human body, $\mathrm{m} / \mathrm{s}$

$\mathrm{p}_{\mathrm{a}}=$ partial water vapor

$\mathrm{h}_{\mathrm{c}}=$ convective heat transfer coefficient, $\mathrm{W} / \mathrm{m}^{2}{ }^{\circ} \mathrm{C}$

$\mathrm{t}_{\mathrm{cl}}=$ surface temperature of the clothing, ${ }^{\circ} \mathrm{C}$

During the activity as example walking or running, the relative air velocity $\left(\mathrm{v}_{\mathrm{ar}}\right)$ is a function of air speed (v) and metabolic rate (Stanton et al., 2005). The relative air velocity $\left(\mathrm{v}_{\mathrm{ar}}\right)$ is written in equation 2 below.

$v_{a r}=v+0.005(\mathrm{M}-58)$

Table 2 shows clothing isolation as one part of personal factor to calculate the PMV index. The value of table 2 is explored from ISO 9920-1990 (1990), Ergonomics of the Thermal Environment: Estimation of the Thermal Insulation and Evaporative Resistance of a Clothing Ensemble, International Organization for Standardization, Geneva. There are some clothing ensembles with explanation of insulation level in unit clo or $\mathrm{m}^{2} . \mathrm{K} / \mathrm{W}$, as example somebody wear panties, T-shirt, shorts, light socks and sandals will have insulation 0.30 clo or matched with $0.050 \mathrm{~m}^{2} . \mathrm{K} / \mathrm{W}$. The insulation level of cloths will be used in determining of PMV index.

Metabolic rate varies over a wide range, depending on the activity, the person, and the conditions under which the activity is performed. Table 3 explains metabolic rate level for any different activities, e.g. standing position with light activities like shopping and working in laboratory has metabolic rate 70 $\mathrm{W} / \mathrm{m}^{2}$ or 1.2 met. A detailed explanation of the measurement and evaluation of metabolic rate as well as a comprehensive collection of metabolic rates for

\begin{tabular}{|c|c|c|c|}
\hline \multirow[t]{2}{*}{ No } & \multirow[t]{2}{*}{ Clothing Ensemble } & \multicolumn{2}{|c|}{$\begin{array}{l}\text { Insulation of Entire } \\
\text { Clothing }\left(\mathrm{I}_{\mathrm{d}}\right)\end{array}$} \\
\hline & & clo & $\mathrm{M}^{2} \mathrm{~K} / \mathrm{W}$ \\
\hline 1 & $\begin{array}{l}\text { Panties, T-shirt, shorts, light } \\
\text { socks, sandals }\end{array}$ & 0.30 & 0.050 \\
\hline 2 & $\begin{array}{l}\text { Panties, petticoat, stockings, } \\
\text { light dress with sleeves, sandals }\end{array}$ & 0.45 & 0.070 \\
\hline 3 & $\begin{array}{l}\text { Underpants, shirt with short } \\
\text { sleeves, light trousers, light } \\
\text { socks, shoes }\end{array}$ & 0.50 & 0.080 \\
\hline 4 & $\begin{array}{l}\text { Panties, stockings, shirt with } \\
\text { short sleeves, skirt, sandals }\end{array}$ & 0.55 & 0.085 \\
\hline 5 & $\begin{array}{l}\text { Underwear, shirt, trousers, } \\
\text { socks, shoes }\end{array}$ & 0.70 & 0.110 \\
\hline 6 & $\begin{array}{l}\text { Panties, petticoat, stockings, } \\
\text { dress, shoes }\end{array}$ & 0.70 & 0.105 \\
\hline 7 & $\begin{array}{l}\text { Panties, shirt, skirt, sweater, } \\
\text { thick knee, socks, shoes }\end{array}$ & 0.90 & 0.140 \\
\hline 8 & $\begin{array}{l}\text { Panties, shirt, trousers, jacket, } \\
\text { socks, shoes }\end{array}$ & 1.00 & 0.155 \\
\hline
\end{tabular}
difference activities can be found in ISO/WD 89961999.

Table 2. Thermal Insulation for Typical Combinations of

\begin{tabular}{|c|c|c|c|}
\hline \multirow{2}{*}{ NO } & \multirow{2}{*}{ Activity } & \multicolumn{2}{|c|}{ Metabolic Rate } \\
\hline & & $\mathrm{W} / \mathrm{m}^{2}$ & met \\
\hline 1 & Reclining & 46 & 0.8 \\
\hline 2 & Seated, relaxed & 58 & 1.0 \\
\hline 3 & $\begin{array}{l}\text { Sedentary activity (office, dwelling, } \\
\text { school, laboratory) }\end{array}$ & 70 & 1.2 \\
\hline 4 & $\begin{array}{l}\text { Standing, light activity (shopping, } \\
\text { laboratory, light industry) }\end{array}$ & 93 & 1.6 \\
\hline 5 & $\begin{array}{l}\text { Standing, medium activity (shop } \\
\text { assistant, domestic work) }\end{array}$ & 116 & 2.0 \\
\hline 6 & Walking on the level: $2 \mathrm{~km} / \mathrm{h}$ & 110 & 1.9 \\
\hline 7 & Walking on the level: $5 \mathrm{~km} / \mathrm{h}$ & 200 & 3.4 \\
\hline
\end{tabular}
Garments

Source: Stanton et al., 2005

Table 3. Metabolic Rate of Typical Activities

Source: Stanton et al., 2005

\section{COMPUTATIONAL FLUID DYNAMIC (CFD)}

Computational Fluid Dynamics (CFD) is a method of calculating the dimensions, area and volume for fluid medium with using a computational computer to perform calculations on each element of the denominator. The use of CFD is commonly used to predict: 
- Flow and heat

- Mass transfer

- The phase change as the process of melting, condensation and boiling

- Chemical reactions such as combustion

- Mechanical movements such as pistons and fan

- Voltage and pedestal on solid objects

- Bubble electromagnetic

The most fundamental thing to employ the concept of CFD (Solid works software) is to reduce the experiment time and experiment cost. The CFD analysis can be used to predict the air flow parameters e.g. air speed, relative humidity, air temperature, vorticity and mean radiant temperature. The CFD tool can be employed to reduce engineering process in the design process. This is underlying that CFD simulation is very important to understand the characteristics of fluid flow in thermal investigation by looking at the results in the form of graphs, vector, and contours, and even video animation.

\section{RESEARCH METHODOLOGY}

According to the aim of the research as mentioned in introduction, the research will produce some recommendations of new layout and new building shapes with low $\mathrm{HI}$ value (no healthy disturbance) for occupants. The research is started with references of thermal comfort and correlated with Computational Fluid Dynamics (CFD). The research object is outside the building of the Brawijaya University, Malang, Indonesia. The research location of Malang will be influence in air flow characteristics (direction, speed, relative humidity, etc). Malang is located at an altitude between 440-667 meters above sea level, is one of the tourist destinations in East Java because of the potential of natural and climatic owned. It lies in the midst of Malang regency with astronomically $112.06^{\circ}$ - $112.07^{\circ} \mathrm{C}$ East longitude and $7.06^{\circ} \mathrm{C}-8.02^{\circ} \mathrm{C}$ South latitude. Malang climatic conditions during 2008 recorded average temperatures ranging between $27^{\circ}$ C. While the maximum temperature reached $32.7^{\circ} \mathrm{C}$ and minimum temperature of $18.4^{\circ} \mathrm{C}$. Average humidity is $87 \%$ with a maximum moisture content of $99 \%$ and a minimum of $80 \%$. Average of air speed through Malang city is around $8 \mathrm{Km}$ per hour with dominating by south to north wind directions.

All the information and knowledge of the Brawijaya University in early survey are collected and then used to the next step for CAD modeling. The collecting data are:
- Data of the UB facility/building layout

- Data of shape and dimension building

- Data of maximum and minimum air speed through the UB building

- Data of relative humidity around the UB, Malang - Indonesia

- Data of maximum and minimum air temperature through the UB building

CAD model is created based on the data from early survey in CAD software as presented in figure 2 below. The figure clearly shows the building layout and the building shape at the University of Brawijaya (UB), Malang. To do the CFD simulation some scenarios and assumptions should be done correctly. There are 4 scenarios for wind direction: south, north, west and east. Every scenario is simulated in average wind speed and average temperature with relative humidity constant (approximately $87 \%$ at local region). The research did not consider the impact of trees in air flow distribution and also in decreasing the environment temperature.

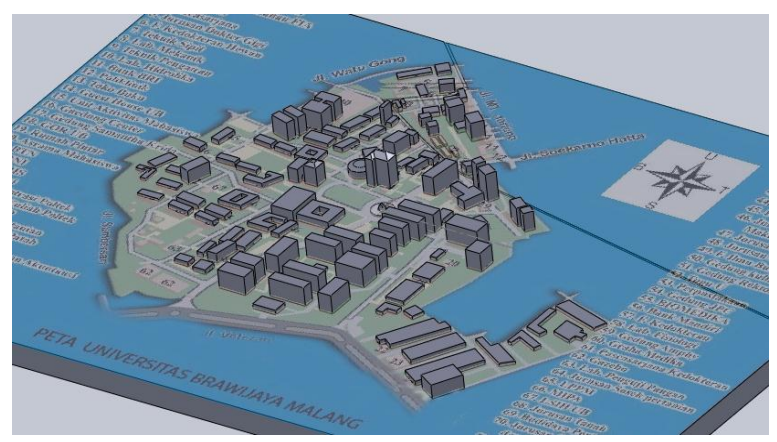

Figure 2. CAD model for CFD simulation to evaluate PMV index.

The simulation is addressed for pedestrians in walking activities with analyzing the people height $=$ $1.7 \mathrm{~m}$ for head, $1.1 \mathrm{~m}$ for trunk, and $0.1 \mathrm{~m}$ for legs/ feet. The analyzing process contents of simulation of wind speed, relative humidity and wind temperature through the UB building. Validation is described by comparing the PMV index from field investigation and the PMV index from simulation value. Air flow characteristics trough the Building will be optimize based on PMV performance.

\section{RESULT \& DISCUSSION}

Figure 3 shows simulation results for existing model in $1.7 \mathrm{~m}$ people height, $87 \%$ relative humidity, $30^{\circ} \mathrm{C}$ air flow temperature and 4 wind directions (north, south, east and west) with speed $8 \mathrm{Km} / \mathrm{h}(2.22$ 
$\mathrm{m} / \mathrm{s}$ ). Generally, all the wind directions give almost the same form distribution of wind speed inside the boundary of the Brawijaya University, Malang. There are some critical places which produce zero wind speed for all wind directions that means giving dangerous situation for thermal comfort. The lower level of wind speed will increase proportionality to the PMV index. According to equation 2 with critical wind speed $8 \mathrm{~km} / \mathrm{h}(2.22 \mathrm{~m} / \mathrm{s})$ and a pedestrian walking with speed $2 \mathrm{Km} / \mathrm{h}$ and metabolic rate 1.9 met $\left(110 \mathrm{~W} / \mathrm{m}^{2}\right)$ will has relative air velocity:

$$
\begin{aligned}
\mathrm{v}_{\mathrm{ar}} & =\mathrm{v}+0.005(\mathrm{M}-58) \mathrm{m} / \mathrm{s} \\
& =2.22+0.005(110-58) \\
& =2.48 \mathrm{~m} / \mathrm{s}
\end{aligned}
$$

According to all the CFD simulations and field measurement for relative humidity, temperature and mean radian temperature, there are no significant difference for all places. As example the temperature and relative humidity for south wind speed have delta maximum - minimum $=0.0037^{\circ} \mathrm{C}$ for air temperature and 0.0169 for relative humidity (figure $3 \mathrm{a}, \mathrm{b}$ ). With the assumption of mean radiant temperature is equivalent to average air temperature, the PMV index can be calculated easily. Based on formula 1, formula 2 and figure 3 with walking activity $2 \mathrm{~km} / \mathrm{h}$, and wearing underpants, shirt with short sleeves, light trousers, light socks, shoes will give the PMV index is 0.957. It can be inferred that the UB environment is generally categorized in slightly warm thermal perception with slight heat stress. Unfortunately, as the existing layout is not well organized will impact on higher PMV index in wind speed $=0 \mathrm{~m} / \mathrm{s}$. According to PMV formula, the critical condition $\left(32.7^{\circ} \mathrm{C}, 99 \%\right.$, $\mathrm{v}=0.26 \mathrm{~m} / \mathrm{s}$ ) will produce PMV index $=2.926$ or in hot thermal perception with strong heat stress.

Sensitivity analysis is used to understand the behavior of microclimatic factors and personals factors in measuring the PMV index. Controlling the sensitive factor is very important to reduce the MPV index and deleting the insensitive factor is beneficially reducing the experiment cost. The research defined 4 control factors (air temperature, wind speed, clothing and relative humidity) and one un-controlling factor of human activity. Figure 4 shows the sensitivity analysis of air temperature $\left({ }^{\circ} \mathrm{C}\right)$ in the PMV index. The range of air temperature is between $20^{\circ} \mathrm{C}$ to $34^{\circ} \mathrm{C}$ will proportionally increase the PMV index. For the Brawijaya University situation with average relative humidity $=87 \%$, walking activity $=2 \mathrm{~km} / \mathrm{h}$, average of relative air velocity $=2.48 \mathrm{~m} / \mathrm{s}$ will has comfortable PMV index for temperature between $22^{\circ} \mathrm{C}$ to $24^{\circ} \mathrm{C}$. The temperature up to $28^{\circ} \mathrm{C}$ will make heat stress for pedestrian. According to the graph, the sensitive value of temperature in determining the PMV index is $\approx$ 0.325 scale $/{ }^{\circ} \mathrm{C}$.
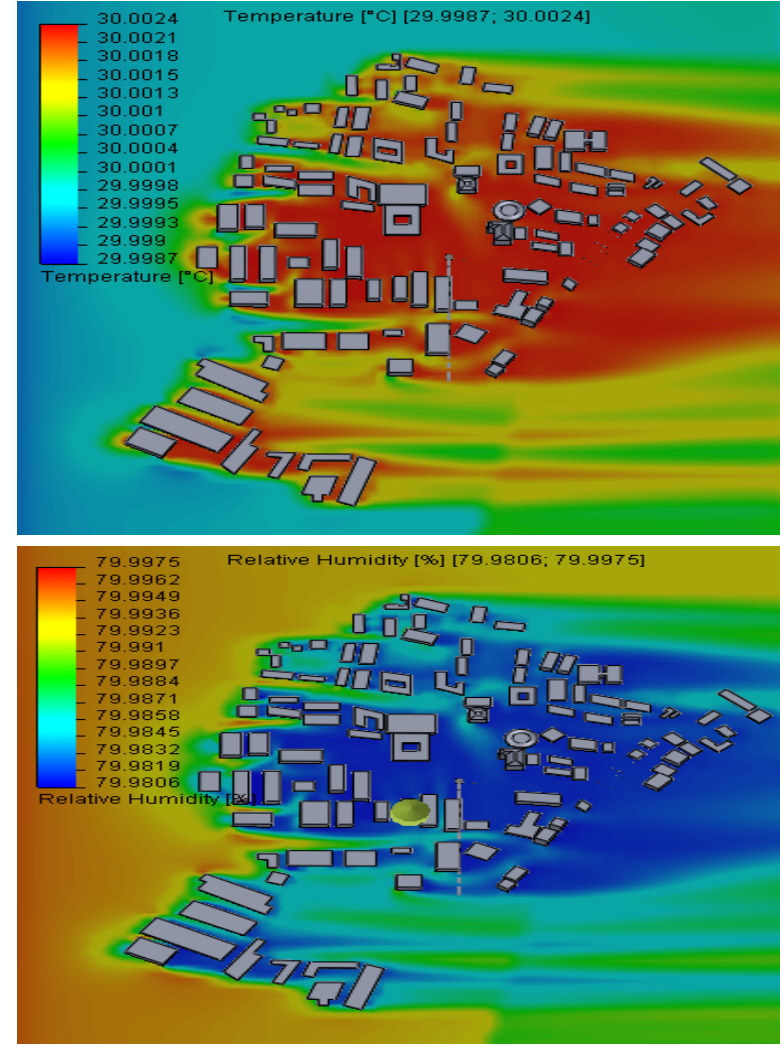

Figure 3. Temperature Configuration (left), and Relative Humidity Configuration in air flow simulation through UB building from the South to North directions (right).

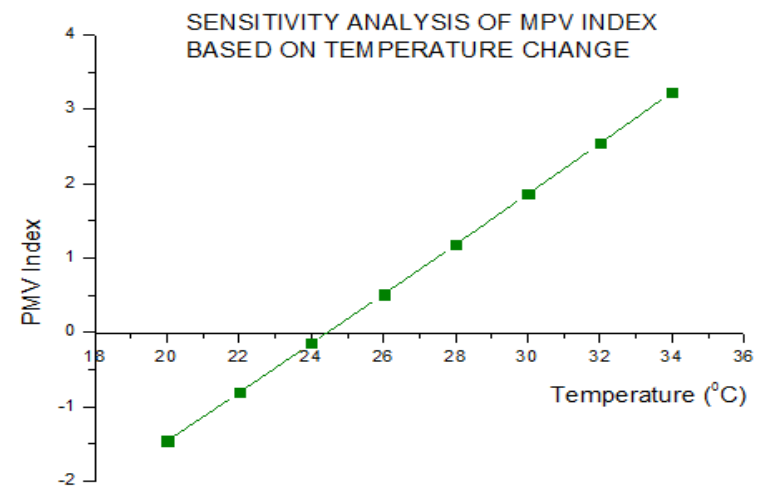

Figure 4. Sensitivity Analysis of MPV Index Based on Temperature Change

Figure 5 shows the sensitivity analysis of relative air velocity $(\mathrm{m} / \mathrm{s})$ in the PMV index. The range of relative air velocity is between $0 \mathrm{~m} / \mathrm{s}$ to $3.5 \mathrm{~m} / \mathrm{s}$ will exponentially decrease the PMV index. For the University of Brawijaya (UB) situation with average relative humidity $=80 \%$, walking activity $=2 \mathrm{~km} / \mathrm{h}$, average of air temperature $=30^{\circ} \mathrm{C}$ will create heat stress for pedestrian in relative air velocity less than 3 $\mathrm{m} / \mathrm{s}$. According to fitted curves plot in exponential graph, the sensitive value of relative air velocity in determining the PMV index is $\approx-0.080$ scale / $(\mathrm{m} / \mathrm{s})$. 
Figure 6 shows the sensitivity analysis of relative humidity (\%) in the PMV index. The range of relative humidity is between 40 to $85 \%$ will proportionally increase the PMV index. For the University of Brawijaya (UB) situation with relative air velocity $=$ $2.48 \mathrm{~m} / \mathrm{s}$, walking activity $=2 \mathrm{~km} / \mathrm{h}$, average of air temperature $=30^{\circ} \mathrm{C}$ will create heat stress for pedestrian in relative humidity upper than $45 \%$. According to fitted curves plot in linier graph, the sensitive value of relative humidity in determining the $\mathrm{PMV}$ index is $\approx 0.007 \mathrm{scale} / \%$.

Figure 7 shows the sensitivity analysis of clothing insulation (clo) in the PMV index. The range of clothing insulation is between 0.30 clo to 1.00 clo will increase the PMV index. For the University of Brawijaya (UB) situation with relative air velocity $=$ $2.48 \mathrm{~m} / \mathrm{s}$, relative humidity $80 \%$, walking activity $=2$ $\mathrm{km} / \mathrm{h}$, average of air temperature $=30^{\circ} \mathrm{C}$ will create heat stress for pedestrian in any clothing insulation based on table 2. According to fitted curves plot in polynomial graph, the sensitive value of clothing insulation in determining the PMV index is $\approx 0.750$ scales/clo.

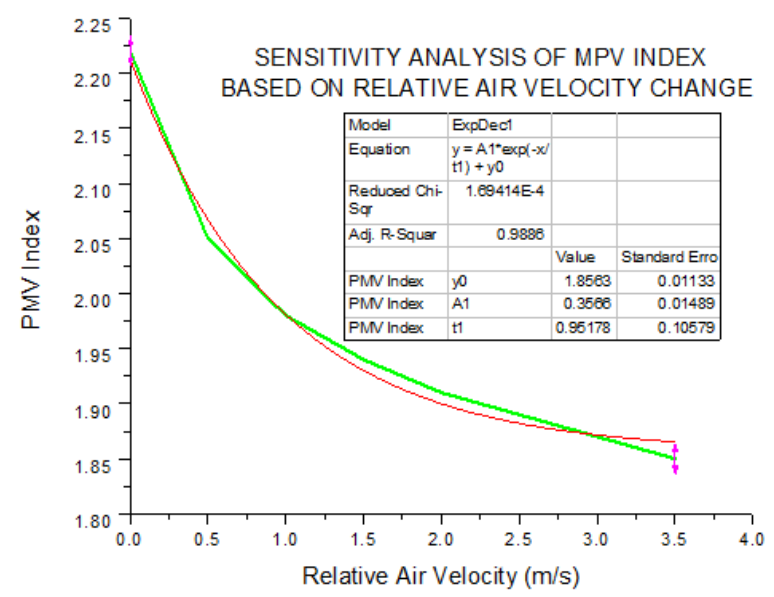

Figure 5. Sensitivity Analysis of MPV Index Based on Relative Air Velocity Change

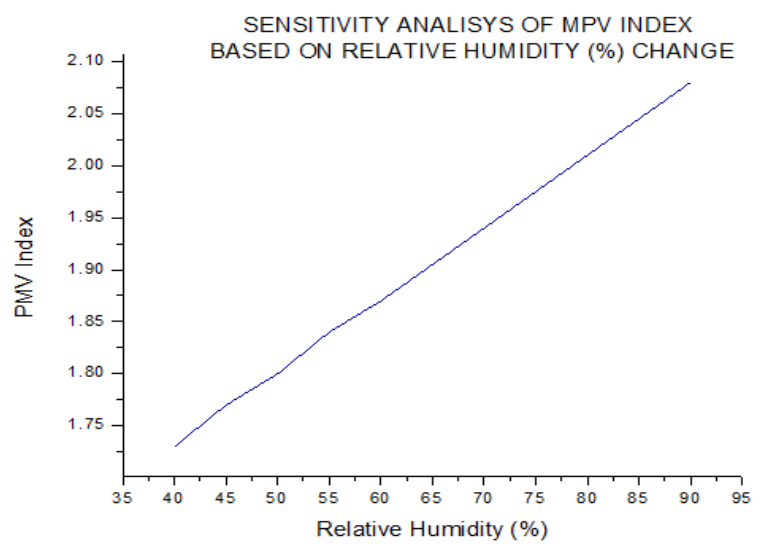

Figure 6. Sensitivity Analysis of MPV Index Based on Relative Humidity Change

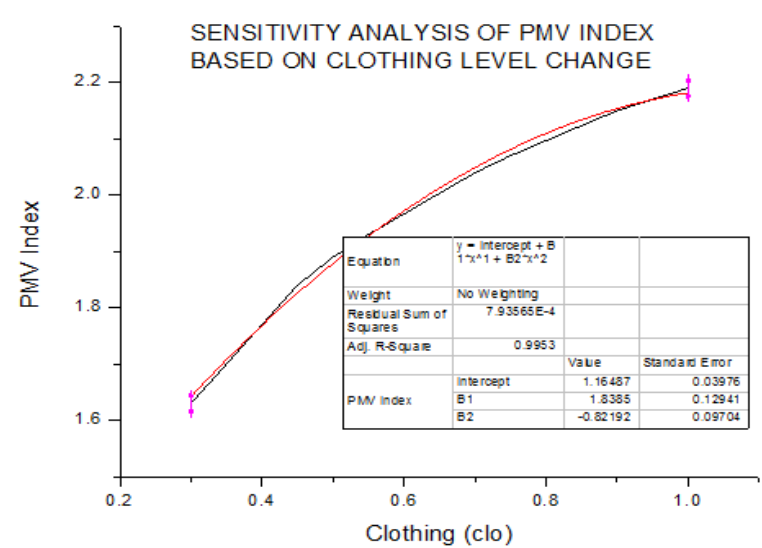

Figure 7. Sensitivity Analysis of MPV Index Based on Clothing Change



Figure 8. Cross Sectional Shape of Recommended Building Based on Symmetric Air Foil.

According to six factors above, there is the serial of easy of or possible to modify the value:

- Clothing insulation

- Activity level

- Air velocity

- Mean radiant temperature

- Relative humidity/Temperature

The research focused on how to reduce the PMV index based on increasing the air velocity and reducing air temperature by looking for the best building and layout design. To keep the air flow in higher speed, shape of building supposes to following the symmetrical air foil with drag aspect ratio 3.5 (length $=35 \mathrm{~m}$ and width $=10 \mathrm{~m}$. The collaboration of standard building and symmetrical air foil rule can be described in figure 8 bellow. The building with length $=20 \mathrm{~m}$ and width $=10 \mathrm{~m}$ will has sectional area $165.42 \mathrm{~m}^{2}$.

Figure 9 shows the air flow simulation through the modification building (based on air foil dimension) in temperature $=27^{\circ} \mathrm{C}$, relative humidity $=87 \%$ and south air flow direction. According to the picture, there are increasing the speed level in four locations of investigation from $0.61 \mathrm{~m} / \mathrm{s}$ to $0.97 \mathrm{~m} / \mathrm{s}$ (point 1 ), from $2.38 \mathrm{~m} / \mathrm{s}$ to $2.61 \mathrm{~m} / \mathrm{s}$ (point 2), from $0.16 \mathrm{~m} / \mathrm{s}$ to $2.71 \mathrm{~m} / \mathrm{s}$ (point 3) and from $0.21 \mathrm{~m} / \mathrm{s}$ to $2.28 \mathrm{~m} / \mathrm{s}$ (point 4) . Additional speeding of air flow did not 
significantly reducing temperature and relative humidity. As consequence, the PMV index is just depending on the variety of wind speed. Based on formula 1 , it can be seen that PMV in point 1 is 1.188 reducing to be $\mathrm{PMV}=1.113$, point 2 the $\mathrm{PMV}=0.943$ reducing to 0.925 , point 3 the $\mathrm{PMV}=1.390$ reducing to 0.917 and point 4 the $\mathrm{PMV}=1,316$ reducing to 0.952 . Overall, it can be concluded that modified the building into symmetric shape can reduce heat stress level for sidewalk (described in point 2, 3 and 4) from the PMV index $>1$ to be PMV index $<1$.

The next modification of microclimate around the Brawijaya University is building the water pool to reduce temperature of air flow through the building. On the otherhand, water pool can increase reltive humidity as evaporation process (increase PMV index). As consequence, air flow simulation model is used to explain the impact of water pool near building with PMV index investigation. According to space available in location, the size of pool water is with length $=8 \mathrm{~m}$, width $=4 \mathrm{~m}$ and dept $=3 \mathrm{~m}$ in $6 \mathrm{~m}$ in front of the building. Figure 10 explains the configuration both of relative humidity and temperature. From the simulation results, it can be determined that temperature reducing at average $=0.0039^{\circ} \mathrm{C}$ and relative humidity increasing at average $0.020 \%$. By using the formula 1, the PMV index level reduced by average $0.1 \%(0.001)$. It means that water pool give small positive impact in human comfort. Two scenarios for decreasing the heat stress level as indicated by PMV index has been presented by creating the building based on symetric air foil shape dimension and water pool layout design. The air foil structure sucesfully reduced PMV index more than 0.4 scale, but water pool is insinificantly reducing the PMV index with just only 0.001 scale.

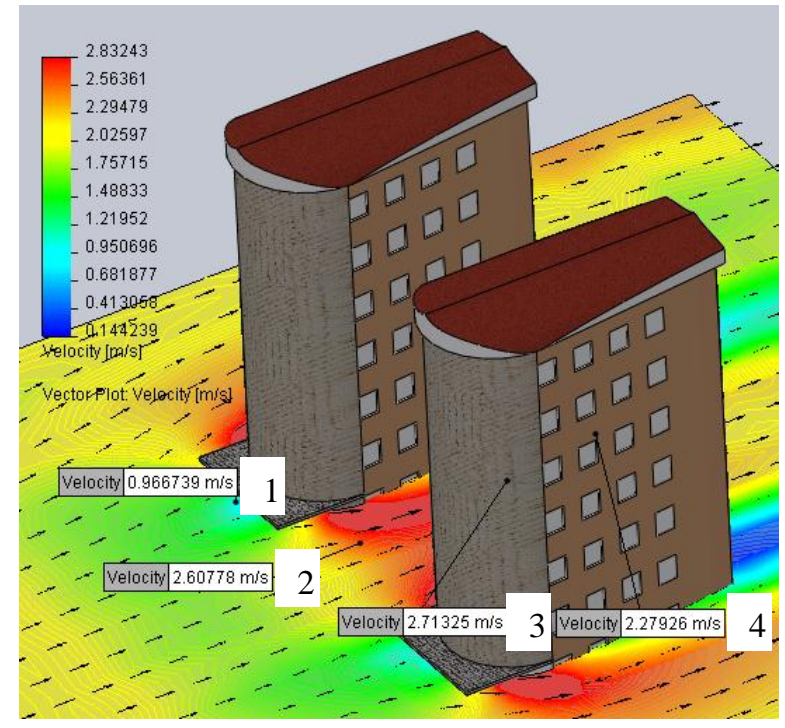

Figure 9. Plot of Velocity Contour on the Building Based on Symmetric Shape.

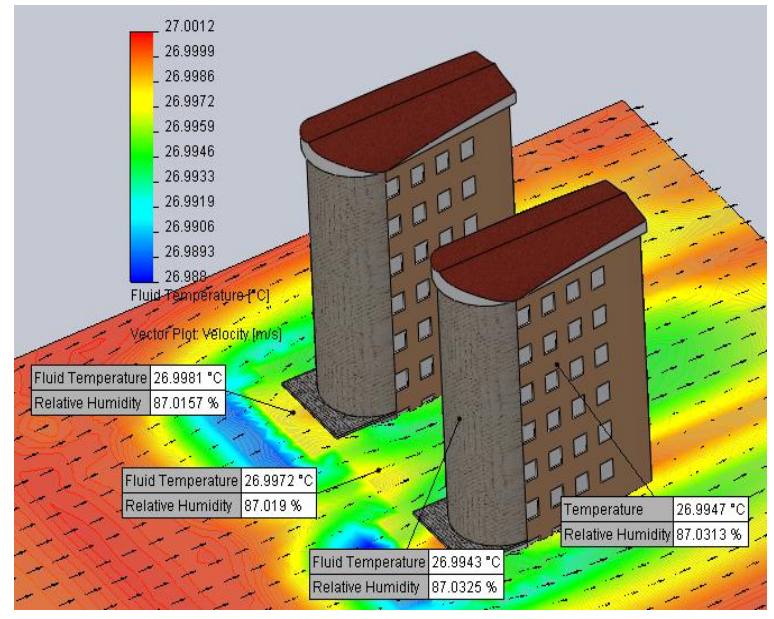

Figure 10. Plot of Fluid Temperature and Relative Humidity as Impact of Water Pool.

The suggestion actions for reducing the PMV index to reach the comfortable situation around the Brawijaya University building should be maintain in the future research. The concept of eco - environment must put in the regulation such as plant more tress, special material building and etc.

\section{CONCLUSION}

The research has successfully presented a 3D CAD model for the Brawijaya University layout and then simulated it by the CFD to configure the air flow characteristics through the Brawijaya University buildings. The CFD simulations can be employed to configure the distribution of wind speed, air temperature, relative humidity and mean radiant temperature which are used to predict the PMV index level. According to PMV index evaluation, the existing model of object is categorized in slightly warm thermal perception with slight heat stress level for pedestrian (PMV index $=0.325$ ) in air temperature $27^{\circ} \mathrm{C}$, relative humidity $87 \%$ and in walking activity 2 $\mathrm{Km} / \mathrm{h}$.

The paper shows how the building design has successfully reducing PMV index level by increasing wind speed and reducing temperature through the building. The concept of symmetric air foil guides air flow in streamline position to keep the higher wind speed. The paper shows aspect ratio of dimension is 3.5 (= $35 \mathrm{~m}$ length $/ 10 \mathrm{~m}$ width) will contribute reducing PMV index at average $=0.4$ in slightly heat stress. Developing water pool in front of the building will not significantly reducing temperature, on the contrary it will also increasing the relative humidity level. Overall the new layout design (water pool dimension $=8 \mathrm{m \times 4} \mathrm{m} \mathrm{x} 3 \mathrm{~m}$ ) with temperature at around $20^{\circ} \mathrm{C}$ will reduce PMV index in 0.001 . Further 
research is indispensible to optimize water pool design as target of decreasing temperature through the building. It can be possibility done by planting more trees, modified water pool, looking for the best material building, etc.

\section{ACKNOWLEDGMENT}

Thanks to the Ministry of National Education of the Republic of Indonesia for supporting this paper. The authors are also grateful to the Industrial Engineering Department, the Brawijaya University, Malang Indonesia for their extraordinary courage.

\section{REFERENCES}

Bridger, R.S. (2003). Introduction to Ergonomics, Taylor \& Francis, London.

Khalid, S. et al. (2013). Assement of Outdoor Thermal Comfort in Urban Microclimate in Hot Arid Areas, $13^{\text {th }}$ CIBPSA, Chambery, France.

Yayi, A. (2012). Comfort Temperature or the LowIncome Group in a Hot-Humid Climate, Proceeding of $7^{\text {th }}$ Windsor Conference, London UK.
Greenslade, E. et al. (1997). Extremes of Temperature, The Occupational Safety and Health Service, Dept of labour, Wellington, New Zealand.

Koch-Neilsen \& Holger (2002). Stay Cool: A Design Guide for the Built Environment in Hot Climates. Earthscan Publications.

Stanton et.al. (2005). Handbook of Human Factors and Ergonomics Methods. CRC Press.

Fadl, M. S. (2013). CFD Simulation for Wind Comfort and Safety in Urban Area: A case Study of Coventry University Central Campus, International Journal of Architecture, Engineering and Construction, 2(2).

Treeck V. C. (2006). Towards Interactive Indoor Thermal Comfort Simulation, ECCOMAS CFD 2006, Netherland.

Tsuyoshi, H. (2009). Thermal Comfprt in Outdoor Environment, Global Environment Research 4347, Japan.

Varkute S. N. \& Maurya, R.S. (2013). CFD Simulation in Township Planing - A Cas Study, International Journal of Computational Engineering Reserch, 3(3). 